\title{
Efficacy of Albendazole on Gastro-Intestinal Strongyles of Cattle in Ngaoundere (Adamawa-Cameroon)
}

\author{
Mamoudou Abdoulmoumini ${ }^{1 *}$, Salhine Robert ${ }^{1}$, Sevidzem Silas Lendzele ${ }^{2}$, Achukwi Mbunkah Daniel ${ }^{3}$, Rebecca Garabed ${ }^{4}$ \\ ${ }^{1 *}$ Department of Parasitology and Parasitological Diseases, School of Veterinary Medicine and Science, University of Ngaoundéré Po Box 455 \\ Ngaoundéré Cameroon. \\ ${ }^{2}$ Laboratory of the institute of Evolution and Ecology, Department of Comparative Zoology, University of Tübingen, Tübingen, Germany. \\ ${ }^{3}$ TOZA Research Foundation, P.O. 59 Bambili, North West Region, Cameroon. \\ ${ }^{4}$ Department of Veterinary Preventative Medicine, College of Veterinary Medicine, Ohio State University, OH, USA.
}

${ }^{*}$ Correspondence to: Mamoudou A, Department of Parasitology and Parasitological Diseases, School of Veterinary Medicine and Science, University of Ngaoundéré Po Box 455 Ngaoundéré Cameroon; E-mail: mamoudou.abdoulmoumini@yahoo.fr

Received: March 14, 2018; Accepted: March 24, 2018; Published: April 05, 2018;

\begin{abstract}
The present study aimed at identifying the gastro-intestinal Strongyles of cattle and to evaluate the effect of albendazole on their population dynamics throughout the year. Three cattle farms located in the village of Velambai were used for the study. 175 animals were screened through coprological examination to assess their infection rate (IR) with gastro-intestinal nematodes. 50 Goudali were monitored from April 2015 to March 2016 . Of these animals selected, 25 of them received albendazole on day 0 (D0) and constituted the treated group while the other 25 received nothing and stood for the non-treated group. Faeces were examined using the McMaster method to evaluate the efficacy of treatment and to monitor changes in faecal shedding of Strongyles. Faeces from animals were cultured to recover the infective L3 larval stage of Strongyles by the Baermann method. The survey revealed that Strongyles, Strongyloides and Toxocara were the main gastro-intestinal helminths infecting cattle with IRs of $64.5 \%, 15 \%$ and $24.1 \%$ respectively. Deworming at the beginning of the rainy season reduced the shedding of helminth eggs (EPG $<400)$ throughout the season. Percentage reduction in the number of eggs per gram of faeces (EPG) from Strongyles was $68 \%$ at day 30. Stool culture revealed the presence of four types of Strongyles with varying abundance depending on the genus (Trichostrongylus, Haemonchus, Cooperia and Oesophagostomum), animal group and month. The genera Trichostrongylus and Haemonchus were dominant throughout the year. Haemonchus spp were significantly sensitive to albendazole between D30 to D90. On D120, albendazole lost its effect with the genus Haemonchus which resulted in the re-infection of the animals, whereas this effect was rather late for the genus Oesophagostomum (from D270).
\end{abstract}

Key words: Gastro-intestinal helminths, stool culture, deworming, Albendazole, Ngaoundere, Cameroon.

\section{Introduction}

Livestock is an important source of income in most developing countries and contributes to food security. In Africa, it contributes upto $10-20 \%$ of the gross domestic product (GDP) [1]. However, in the Adamawa Region of Cameroon like in other African regions, this sector is subject to several constraints including diseases [2] for instance gastro-intestinal cattle strongylosis [1]. Strongylosis contributes to emaciation especially at the end of the dry season [3] and leads to production loss. The control of these pathologies in order to improve the individual productivity of cattle is therefore a necessity in a context already marked by the rapid growth of the human population and the increasing demand for animal protein, both in Cameroon and in all developing countries. In Cameroon, particularly in the Adamawa region, deworming has become a common practice by Veterinarians, but most often by breeders themselves and in most cases without seeking for medical advice [1-4]. For almost two decades now, the anti-parasitic pharmaceutical industries have made tremendous advancements in terms of developing new molecules with improved anthelminthic properties, but parasitism still prevails [5]. Just of recent, albendazole was introduced as an essential anthelmintic, but its usage is sometimes abused [6]. In a context where modern breeding is increasingly confronted with problems related to chemical residues (food safety) and the appearance of parasitic resistant strains to the main families of pharmaceuticals around the world, this has exposed the limitations of a systematic deworming and makes the implementation of treatment protocols essential [3-7]. Studies on the efficacy of albendazole on gastrointestinal parasites in calves in the dry season in vina by Sakativa [8] and Sassa et al. [9] in sheep in Mbé in the Adamawa region, revealed the significant impact of gastro-intestinal parasitosis on the productivity of ruminants in the respective areas. But a longitudinal follow-up study on the effect of deworming on the dynamics of gastro-intestinal Strongyles of adult cattle in Vina is lacking. The purpose of this study was to determine the prevalence of cattle helminths and to evaluate the impact of albendazole treatment on faecal egg counts. 


\section{Material and Methods}

\section{Study zone}

This field trial was carried out in Velambai, geographically located between latitude $6^{\circ}$ and $8^{\circ}$ North and between longitude $11^{\circ}$ and $15^{\circ}$ East. This area is called the 'Castle of water' because large number of rivers in the country originates from this locality. Resulting from the emergence of the old crystalline basement, the department of Vina is elevated at an altitude between 1000 and 1300 meters [10]. The high altitude of this region provides a relatively cool climate with temperatures ranging between $22-25^{\circ} \mathrm{C}[11]$. The climate is of the Sudanese tropical type with two seasons: the dry season that occurs from November to March, followed by the wet season. The average annual rainfall is 900 $\mathrm{mm}$ to $1500 \mathrm{~mm}$. This area is covered by discontinuous vegetation consisting of savanna grasses such as Hyparrheenia, Panicum and Sporobolus. Three cattle farms were randomly selected from the Velambai locality, where 175 animals of the Goudali cattle breed of both study groups received food supplements such as molasses and cotton seed cake (two to three times a week) during the dry season. Coprological assays were carried out on day zero (D0). A study on the prevalence of gastrointestinal parasites was performed on all the 175 selected animals. Faeces was collected from the rectum, stored in a cooler and transported to the Wakwa Agricultural Research Institute for Development (IRAD) Parasitology laboratory for analysis using the McMaster method. The egg per gram of faeces (EPG) $\geq 50$ was noted [12-13].

To evaluate the impact of deworming using albendazole on the population dynamics of gastrointestinal strongyles, two groups of cattle were used to monitor the variation of gastro-intestinal Strongyles for 12 months post albendazole administration. 50 cattle of both sexes were selected from the 175 cattle initially selected. These 50 animals were divided into two groups: treated group of 25 cattle including 8 males and 17 females and an untreated group of 25 cattle including 11 males and 14 females. Only the animals in the experimental group (treated group) had undergone deworming with albendazole in bolus (7.5mg / Kg per os). Fecal samples were taken once a month for 12 months (from April 2015 to March 2016), ie D0, D30, D60, D90, D120, D150, D180, D210 D240, D270, D300 and D330 after the administration of albendazole. Faecal samples of the animals were cultured in a saturated salt solution and larvae were isolated using the Baermann method [14]. Larval identification was carried out using the identification key of [15].

\section{Data Analysis}

The One-way analysis of variance (ANOVA) was performed to compare the effect of age, sex, type with infection prevalence. To compare different infection rates of nematodes, the $X^{2}$ test was performed. The EPG averages of the two groups of cattle were compared using the Student t-Test. These different statistics were carried out using the $\mathrm{R}$ version 3.2 software. The efficacy of the treatment with albendazole was calculated at day 30 using the method of Presidente [16].

\section{Results}

The identification of gastro-intestinal helminths in cattle led to the identification of helminth eggs of veterinary importance i.e. strongyles; Strongyloides papillosus and Toxocara vitulorum. Strongyles were the most common $(64.7 \%)(170.65 \pm 7.67)$. Age and sex were statistically significant $(\mathrm{p} \leq 0.05)$ with infection prevalence. Young animals $(1-2$ years) were the most infected (85\%) and males $(76.92 \%)$ were more infected than females $(60.29 \%)$ (Table 1). The prevalence of Toxocara vitulorum was $24.1 \%$ (20.3-28). The young recorded a prevalence of $24.28 \%$ more infested than adults with a significant difference $(\mathrm{p} \leq$ 0.05) (Table 1). The prevalence of Strongyloides was $12.3 \%$ (8.6-16) (Table 1).

\section{Effect of albendazole on the EPG of gastro-intestinal Strongyles}

From D30 to D120 after treatment with albendazole, there was a significant decrease $(\mathrm{p}<0.001)$ in faecal excretion of Strongyles eggs in the treated group (Table II). The EPG's percentage reduction was $67.15 \%$. In the untreated group, monthly EPG averages were moderate $(\mathrm{EPG}<400)$ throughout the study period. Mean faecal egg shedding variations with respect to Strongyles revealed a peak on D90, but decreased to 68EPG on D330 (Table 2).

After the coproculture of the L3 nematode larval stages, the following nematodes: Haemonchus spp., Trichostrongylus spp., Cooperia spp., and Oesophagostomum spp were identified at the beginning of the rainy season. The proportion of the nematodes recovered from the different parts of the gastro-intestinal tract was: Abomasum parasites: Trichostrongylus spp. (42\%) and Haemonchus spp. (28\%), Parasite of the small intestine, of Cooperia spp. (18\%), Parasite of the large intestine, Oesophagostomum spp. (12\%). These four genera were present throughout the study in all the sampled herds. The variations of the average monthly intensities of the L3 of the Strongyles showed an overall monthly variation of Strongyles. Trichostrongylus sp. was the most common species from April to October with the lowest infection rate (IR) in January. Haemonchus sp. had two peaks: the first one in August and the second higher rate (56\%) in January. Cooperia $s p$ peaked in September while Oesophagostomum presented two peaks, the first in October and the second in late January and declined with its lowest rate in March (Figure 1).

The impact of deworming on Trichostrongylus sp. population was remarkable on D90 in the month of July and the percentage L3 shedding significantly declined in January (Figure 2).

Haemonchus in the treated group responded to treatment by recording an L3 reduction from 29\% (April-D0) to $12 \%$ in May (D30) post albendazole administration (p.a.a). A statistical significant difference ( $\mathrm{p} \leq 0.05$ ) was observed between the two groups (treated-E and untreated-T) on days 30 and 60 (Figure 3 ).

The mean infection prevalence of Cooperia was $12.1 \%$ in the treated group and $13.4 \%$ in the untreated counterpart. This frequency in the treated group significantly decreased $(\mathrm{p} \leq 0.05)$ at D30 as compared to the untreated group (Figure 4). The occurrence peak of Cooperia sp. in the treated group was observed on D30, > one month after that of the untreated group (Figure 4). 
Table 1. The prevalence of gastro-intestinal nematodes

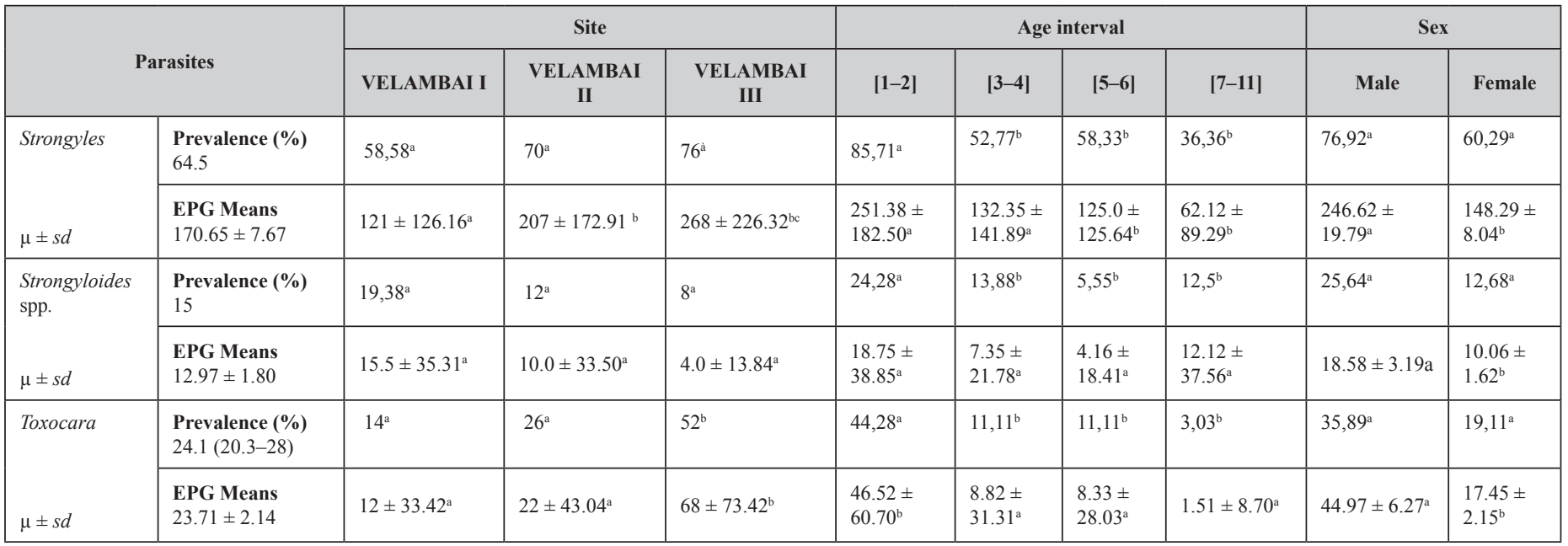

$a, b, c, d$ : values with different superscript letters on the same line are significantly different $(p<0.05)$. $\mu$ : mean. sd: standard deviation, EPG: egg per gram

Table 2. Effect of albendazole on the EPG of gastro-intestinal Strongyles

\begin{tabular}{|c|c|c|c|c|}
\hline Period & Treated group $(\mu \pm s d)$ & Non-treated group $(\mu \pm s d)$ & P-value & Significant levels \\
\hline April $\left(\mathrm{D}_{0}\right)$ & $204 \pm 170.73$ & $268 \pm 226.33$ & 0.265 & NS \\
\hline May $\left(D_{30}\right)$ & $86 \pm 65.38$ & $344 \pm 162.86$ & 0,000 & $* * *$ \\
\hline June $\left(D_{60}\right)$ & $180 \pm 139.19$ & $330 \pm 158.77$ & 0.000 & $* * *$ \\
\hline July $\left(D_{90}\right)$ & $179.17 \pm 207.95$ & $381.25 \pm 181.67$ & 0,000 & $* * *$ \\
\hline August $\left(D_{120}\right)$ & $202.17 \pm 188.58$ & $360.41 \pm 174.44$ & 0.004 & $* * *$ \\
\hline September $\left(D_{150}\right)$ & $190.91 \pm 243.80$ & $291.67 \pm 155.11$ & 0.106 & NS \\
\hline October $\left(\mathrm{D}_{180}\right)$ & $204.35 \pm 180.22$ & $277.08 \pm 129.36$ & 0.121 & NS \\
\hline November $\left(D_{210}\right)$ & $46.87 \pm 71.81$ & $127.08 \pm 141.41$ & 0.024 & $*$ \\
\hline December $\left(\mathrm{D}_{240}\right)$ & $33.33 \pm 48.80$ & $147.83 \pm 154.83$ & 0.003 & $* * *$ \\
\hline January $\left(\mathrm{D}_{270}\right)$ & $60.00 \pm 91.03$ & $135.29 \pm 125.95$ & 0.06 & NS \\
\hline February $\left(D_{300}\right)$ & $75.00 \pm 106.46$ & $68.18 \pm 83.87$ & 0.833 & NS \\
\hline $\operatorname{March}\left(\mathrm{D}_{330}\right)$ & $103.13 \pm 107.19$ & $145.24 \pm 108.29$ & 0.247 & NS \\
\hline
\end{tabular}

*: significatif; **: more significatif; ***: most significatif; $\mu$ : mean; sd: standard deviation, NS: no significant difference.

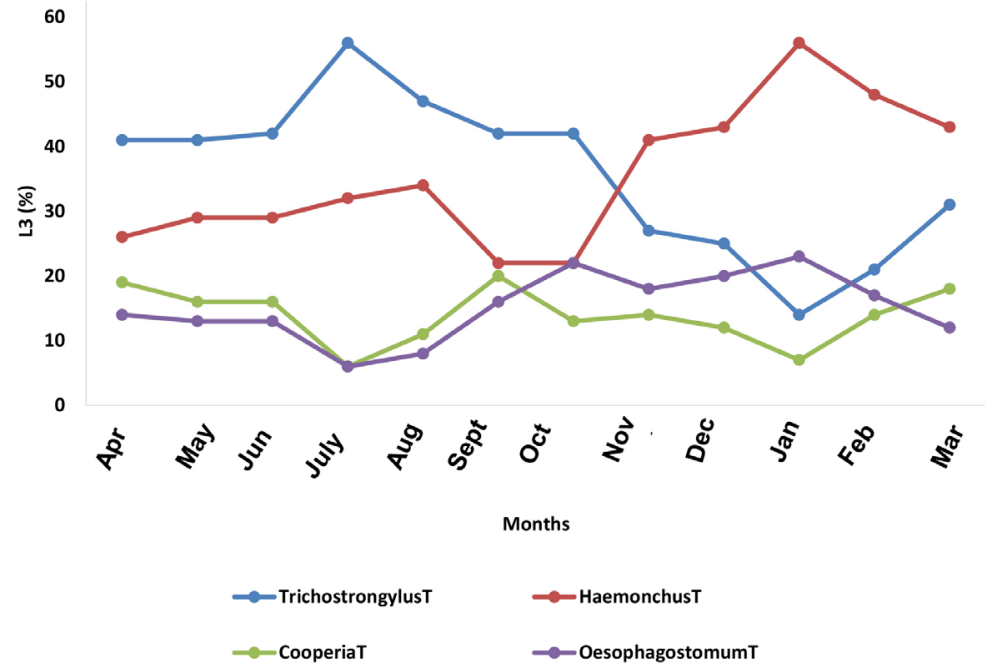

Figure 1. Monthly evolution of the L3 stages of the species of the genera of helminthes identified (T, non-treated animals) 


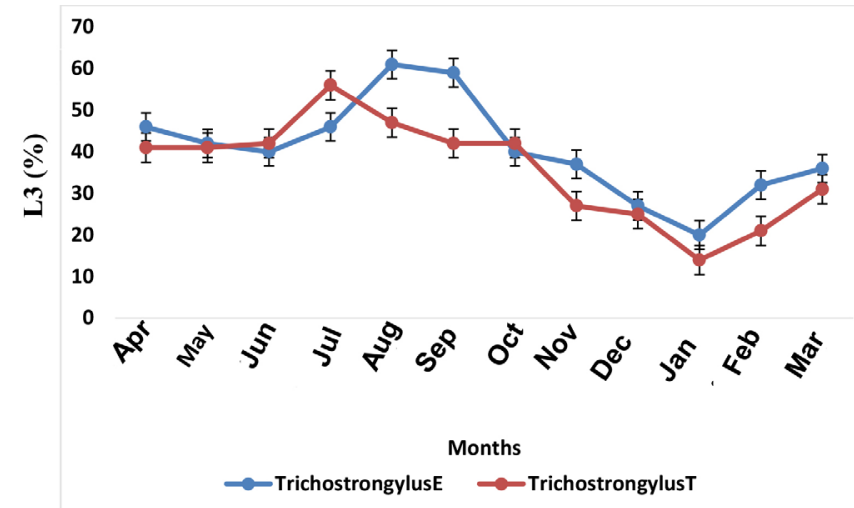

Figure 2. Effect of albendazole on Trichostrongylus sp. (E, treated group and T, nontreated group)

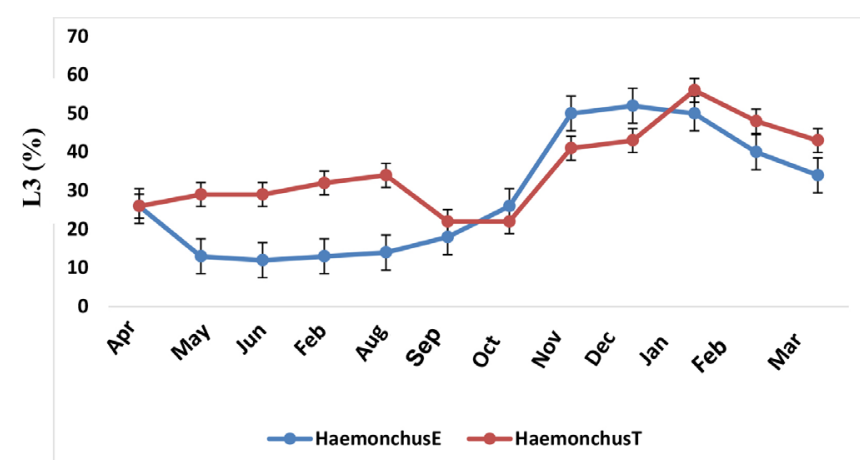

Figure 3. Effect of albendazole on Haemonchus sp. (E, treated group and T, non-treated group)

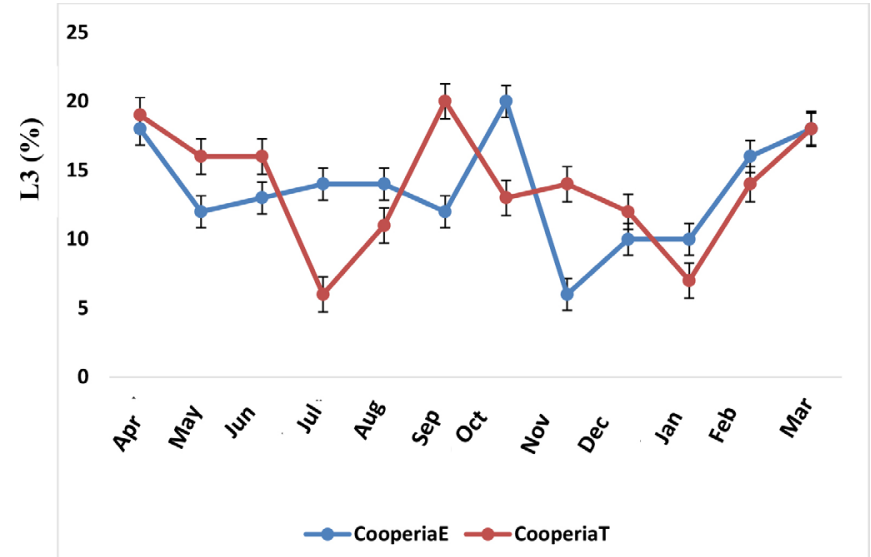

Figure 4. Effect of albendazole on Cooperia sp. (E, treated group and T, non-treated group)

Oesophagostomum $\mathrm{sp}$ in the treated group decreased more than that of the untreated group from September (Figure 5). Its peak in the treated group was observed in May. In the untreated group, two L3 occurrence peaks were noticed, the first one in October and the second in January (Figure 5).

\section{Discussion}

\section{Prevalence of gastrointestinal nematodes}

Of the 175 cattle sampled in three farms in Velambai, 113 (64.5\%) shedded Strongyle eggs (mean: $170.65 \pm 7.67$ ). This low average EPG observed could be justified by the extreme weather conditions of the dry season which might have limited the survival of the infestive larvae and consequently the parasite load [17], although the effect of larval hypobiosis cannot be ruled-out [18]. This result is close to the $69.57 \%$ observed in calves in the Vina by Sakativa [8]. The prevalence of Strongyles was higher in the Velambai 1 farm $(76 \%)$ than in the Velambai 2 and Velambai 3 farms (70\% and 58.58\% respectively) with a statistically significant difference between the three farms. These results are due to pasture management. Indeed, the animals of Velambai 1 and 2 were regularly dewormed which could have reduced the parasite load in these sites. This finding is similar to that of Sassa et al., [9] in small ruminant farms in Vina. Our results show that Toxocara sp. was frequent in the young animals (24.28\%). Age and sex had statistically significant $(\mathrm{p} \leq 0.05)$ effects on Toxocara sp occurence. The prevalence of Strongyloides was $12.3 \%$. This prevalence is close to the $9 \%$ observed by Ntonifor et al., [4] in the Jakiri area, but far below the $75.5 \%$ obtained by Chollet et al., [3] in calves 0-12 months of age in the North and Far North of Cameroon. The low IR here could be due to the average age of the animals (three years six months). Indeed, with Strongyloides there was a strong immunity against this parasite in cattle from the age of 6-9 months [13].

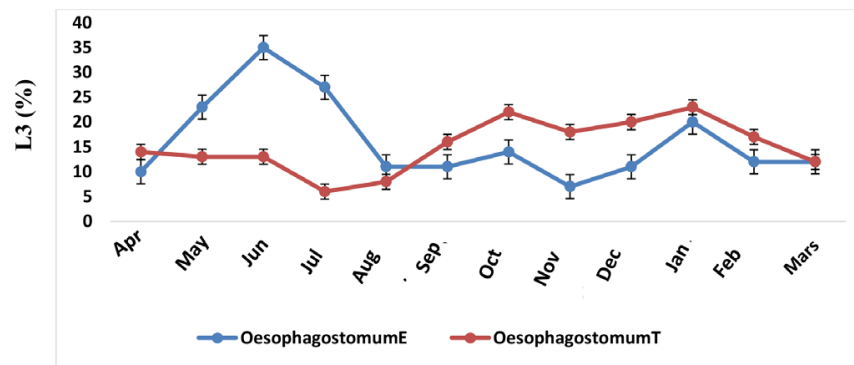

Figure 5. Effect of albendazole on Oesophagostomum sp. (E, treated group and T, non-treated group)

\section{Effect of albendazole on faecal shedding of Strongyles}

After one month of treatment, there was a significant decrease ( $p$ $\leq 0.05$ ) in the level of faecal egg shedding of Strongyles eggs in cattle receiving albendazole. This result corroborate with those observed in some studies on the resistance of gastro-intestinal Strongyles of ruminants to anthelmintics [19-9]. The percentage response to treated by this group was $68.7 \%$, revealing a form of resistance to albendazole. In fact, in this study, $60 \%$ of the animals were adult cattle (more than two years old). These animals could have received several treatments with albendazole, resulting in Strongyles resistance to this molecule [13]. In the untreated group, OPG monthly averages were maintained at a moderate level $(\mathrm{EPG}<400)$ throughout the year. This result confirmed the effect of the rainy season on the variation of Strongyles eggs. Chiejina and Behnke [20] showed that small rains at the end of the dry season resulted in the development of the infective larvae on the pasture. Acquired immunity might have maintained a moderate level of EPG since the group of cattle examined consisted of $60 \%$ of animals over two years old. This finding corroborates with that of Elele et al., [21] on cattle in Port Harcourt, Nigeria. 


\section{Variation of the larval population of Strongyles}

This study revealed multiple infections in cattle in the Adamawa region of Cameroon and this parasitism was similar to that already reported in cattle in many countries in Africa including Burkina Faso [22], Senegal [18] and Cameroon in small ruminants [9]. Similar results with the predominance of Haemonchus and Trichostrongylus genera were also obtained in sheep in Brazil by Klauck et al., [23]. The antagonistic variation between Trichostrongylus sp and Haemonchus could be due to ecological niche competition as the two parasites share the same habitat (abomasum) [24]. On the other hand, this variation on the genera Cooperia (parasite of the small intestine) and Oesophagostomum (parasite of the large intestine) was rather due to an indirect mechanism occuring through the stimulation of the immune reaction of the host or non-specific inflammatory reactions [24]. The effect of deworming on Trichostrongylus $s p$ was observed on the treated group on D90. But this difference was not statistically significant ( $p>0,05)$. Roeber et al., [25] and Demelash et al., [26] both observed this low sensitivity of Trichostrongylus sp to albendazole in sheep in Australia and cattle in Ethiopia respectively. The percentage of L3 of Trichostrongylus sp was lower at the end of the rainy season in both treated and untreated groups. Pfukenyi and Mukaratirwa [27] also observed low Trichostrongylus sp. L3 levels at the end of the rainy season, which according to these authors could be low due to the transition in climatic factors of the late seasons (rainy and dry). The percentage of L3 Haemonchus sp in the treated group dropped from $29 \%$ to $12 \%$, one month (D30) p.a.a. Statistical significant differences ( $p \leq 0.05)$ were observed between treated and untreated groups from D30 to D90. The susceptibility of Haemonchus sp to albendazole was also observed in cattle and equines in Morocco by Zoutien et al., [28] and sheep of Mbé in the Adamawa region of Cameroon [9]. The effect of albendazole on Haemonchus sp from D120 in the treated cattle group was reported to witness some sort of re-infection, especially with the presence of untreated animal faecal material reservoirs on the pasture land. The percentage of the L3 stage of Cooperia was average in both groups throughout the duration of the study $(12.1 \%$ in the treated group and $13.4 \%$ in the untreated group). This may be due to its high resistance to extreme climatic conditions, despite its low fertility [3-29-27]. The effect of treatment with albendazole was significantly $((\mathrm{p} \leq 0.05)$ different from the untreated group only at day 30. The percentage of $\mathrm{L} 3$ of Oesophagostomum sp in the treated group decreased more than that in the untreated group from D90. This could be related to their sensitivity to albendazole that appears to be related to the location of adult worms in the digestive tract of cattle. Indeed, Oesophagostomum is a worm of the large intestine, since albendazole was administered as a $500 \mathrm{mg}$ bolus, this would have required some time for the dissolution in the rumen and thus a late maximum concentration in the large intestine. Holsback et al., [30] also noted this form of resistance of Oesophagostomum in calves in Paraná.

\section{Conclusion}

The objective of self-sufficiency in meat products especially in the reduction of the scramble for beef that Cameroon aims at, a new policy on the development of the livestock sector must be established. Our study of gastrointestinal parasites in cattle in Vina demonstrated the validity of the initial hypothesis that gastrointestinal helminths of cattle are predominant in Vina and that the deworming effect of albendazole has an impact on population variation. It showed two peaks in the infestation level during the rainy season with significant intensities, unlike other studies in the area and showed that animals from one to two years were mostly infected. We were able to show the presence of four genera of gastrointestinal Strongyles among which the genera Trichostrongylus and Haemonchus (parasites of the abomasum) were with frequent. Also, it should be noted that deworming at the beginning of the rainy season will keep the animals at a low infection level until the beginning of the dry season. In addition, this study showed that albendazole has a much greater effect on the population of Haemonchus $s p$ and that this effect is late when referring to the population of Oesophagostomum. Treatments could be administered in mid-May (one month after the actual start of the rains) and in late July (second half of the rainy season). Deworming in mid-May will greatly target the genus Trichostrongylus, while doing so at the end of July will greatly target the genus Haemonchus. Finally, this study also revealed high levels of trematode infection that should also be included in control measures. Any proposal for a deworming schedule should be a subject to economic evaluation and should consider the risk of development of resistance to anthelmintics.

\section{Acknowledgements}

This work was supported by the vaccine project. We thank the Department of Parasitology and Parasitological Diseases for the material support. We thank IRAD Wakwa for technical and material assistance.

\section{Conflict of interest}

Authors declare no conflict of interest

\section{References}

1. Chartier C, Itard J, Morel P, Troncy P (2000) Précis de Parasitologie Vétérinaire Tropicale. Paris.

2. Zinsstag J (2000) Nématodes gastro-intestinaux du bétail bovin N'Dama en Gambie: effets sur la productivité et options pour la lutte. Thèse $\mathrm{PhD} \mathrm{N}^{\circ} 11$, Institut de Médecine Tropicale Prince Leopold, Antwerpen, Belgique.

3. Chollet JY, Martrenchar A, Bouchel D, Njoya A (1994) Épidémiologie des parasitoses digestives des jeunes bovins dans le Nord-Cameroun. Revue d'Élevage et Médecine. Vétérinaire des Pays tropicaux. 47: 365-374

4. Ntonifor HN, Shei S J, Ndaleh NW, Mbunkur G N (2013) Epidemiological studies of gastrointestinal parasitic infections in ruminants in Jakiri, Bui Division, North West Region of Cameroon. J Vet Med Anim Hlth 5: 344-352.

5. Radostits OM, Gay CC, Hinchcliff KW, Constable PD (2006) Veterinary medecine: A textbook of the diseases of cattle, horses, sheep, pigs and goats. Tenth Edition, New York, USA, 2162p.

6. Tanguy I (2011) Évaluation de la résistance des strongles digestifs aux anthelminthiques dans les élevages ovins en Bretagne ? 73p. Thèse de Doctorat Vétérinaire, École Nationale Vétérinaire d'Alfort.

7. Wymann $\mathrm{MN}(2005)$ Calf mortality and parasitism in periurban livestock production in Mali, these $\mathrm{PhD}$, Université de Basel, 227p.

8. Sakativa D (2014) Effet de la vermifugation chez les jeunes bovins de l'Adamaoua pendant la saison sèche. Mémoire de Diplôme de Docteur Vétérinaire. Université de Ngaoundéré. 76p.

9. Sassa MA, Agnem EC, Gambo H, Njan Nloga A (2014). Résistance des strongles gastro-intestinaux aux anthelminthiques chez les moutons à Mbé au Cameroun. Revue Africaine de Santé et de Productions Animales 12 : 21-26

10. Letouzey (1968) Situation des resources genetiques forestieres du Nord-Cameroun, Archives de document de la FAO. Departement des forets 3: 12-14 
11. Mbahe RE (1998) Résultats de recherche agricole pour le développement en zone agro-écologique des hautes savanes guinéennes (Adamaoua). In : Comité régional des programmes, 27-28 oct. 1998. Ngaoundéré, Cameroun, Irad, 17 p.

12. Hansen J, Perry B (1995). Épidémiologie, Diagnostic et Prophylaxie des Helminthiases des Ruminants Domestiques (7nd edn). FAO : Rome, Italie.

13. Troncy PM, Chartier C (2000). Helminthoses et coccidioses du bétail et des oiseaux de la basse-cour en Afrique tropicale. In : Chartier C., Itard J., Morel P.C., Troncy P.M., éds, Précis de parasitologie vétérinaire tropicale. Paris, France, Tec \& Doc, $773 \mathrm{p}$.

14. Thienpont D, Rochette F, Vanparys OFJ (1979) Diagnostic de verminose par examen coprologique. Janssen Research Fondation, Beerse, Belgium, 187 p.

15. Thienpont D, Rochette F, Vanparijs O (1995). Diagnostic de verminose par examen coprologique. Janssen Research Foundation: Beerse 187p

16. Presidente PJA (1985) Methods for the detection of resistance to anthelmintics. In: Resistance in Nematodes to Anthelmintic Drugs (Anderson, N., Waller, and P.J. Eds.). Division of Animal Health, CSIRO, Australia. 13-27.

17. Ndamukong KJ1, Ngone MM (1996) Development and survival of Haemonchus contortus and Trichostrongylus sp. on pasture in Cameroon. Trop Anim Health Prod 28: 193-198. (crossref)

18. Ndao M1, Pandey VS, Zinsstag J, Pfister K (1995) Effect of a single dry season anthelmintic treatment of N'Dama cattle on communal pastures in The Gambia. Vet Res Commun 19: 205-213. (crossref)

19. Gasbarre L, Larry C, Smith L, Patricia E, Pilitt A (2009) Further characterization of a cattle nematode population with demonstrated resistance to current anthelmintics Vet Parasitol 166: 275-280.

20. Chiejina SN, Behnke JM (2011). The unique resistance and resilience of the Nigerian West African Dwarf goat to gastrointestinal nematode infections. Parasites \& Vectors 4: 12
21. Elele KO, Owhoeli, Gboeloh LB (2013) Prevalence of species of helminths parasites in cattle slaughtered in selected abattoirs in Port Harcourt, south-south, Nigeria International Res Med Sci 1: 10-17.

22. Ouedraogo A, Ouattara L, Kaufmann J, Pfister K (1992) Epidémiologie des nématodes gastro-intestinaux des ruminants au Burkina Faso: Spectre, fréquences et variations saisonnières. In: 7ème Conf. AIMVT, Yamoussoukro, Côte-d'Ivoire. 749-750.

23. Klauck V, Pazinato R, Lopes L S, Cucco D C, De Lima H L, et al. (2014). Trichostrongylus and Haemonchus anthelmintic resistance in naturally infected sheep from southern Brazil. Annals of the Brazilian Academy of Sciences 86: 777-784

24. Dorchies PH, Lacroux C, Levasseur G, Alzieu JP (2002) La paramphistomose bovine. Bulletin des GTV, 13: 87-90.

25. Roeber F, Jex AR, Campbell AJD, Nielsen R, Anderson GA, et al. (2012). Establishment of a robotic, high-throughput platform for the specific diagnosis of gastrointestinal nematode infections in sheep. Int J Parasitol 42: 1151-1158.

26. Demelash K, Alemu F, Niguse A, Feyera T (2014). Prevalence of gastrointestinal parasites and efficacy of anthelmintics against Nematodes in camels in Yabello District, Southern Ethiopia. Acta Parasitologica Globalis 5: 223-231.

27. Pfukenyi DM, Mukaratirwa S (2013). A review of the epidemiology and control of gastrointestinal nematode infections in cattle in Zimbabwe. $J$ Vet Res $80: 12$

28. Zouiten H (2006) Résistance aux anthelminthiques des nématodes parasites du tube digestif chez les ovins et les équidés au Maroc. Université MOHAMMED V-AGDAL (Maroc): 141p.

29. Achi YL1, Zinsstag J, Yao K, Yeo N, Dorchies P, et al. (2003) Host specificity of Haemonchus spp. for domestic ruminants in the savanna in northern Ivory Coast. Vet Parasitol 116: 151-158. (crossref)

30. Holsback L, Da Silva MA, Patelli T H C, Paula De Jesus A, et al. (2014). Resistance of Haemonchus, Cooperia, Trichostrongylus, and Oesophagostomum to ivermectin in dairy cattle in Paraná. Ciências Agrárias, Londrina. 36: 2031-2036.

\section{Citation:}

Mamoudou A, Salhine Robert, Sevidzem Silas Lendzele, Achukwi Mbunkah Daniel, Rebecca Garabed (2018) Efficacy of Albendazole on Gastro-Intestinal Strongyles of Cattle in Ngaoundere (Adamawa-Cameroon). Integr J Vet Biosci Volume 2(2): 1-6 